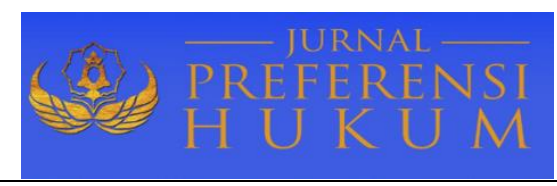

Jurnal Preferensi Hukum | ISSN: 2746-5039

Vol. 2, No. 1 -Februari 2021, Hal. 11-15| Available online at https://www.ejournal.warmadewa.ac.id/index.php/juprehum DOI: https://doi.org/10.22225/jph.2.1.3043.11-15

\title{
PENEGAKAN HUKUM TERHADAP PENYALAHGUNAAN NARKOTIKA
}

Made Ratih Pradnyantari, I Gusti Bagus Suryawan, I Nyoman Sujana

Fakultas Hukum Universitas Warmadewa Denpasar-Bali, Indonesia

\begin{abstract}
Abstrak
Penyalahgunaan Narkotika berdampak sangat buruk terhadap kelangsungan generasi suatu bangsa. Untuk mengantisipasinya perlu kerjasama dari seluruh komponen masyarakat, seperti keluarga, lembaga sekolah dari tingkat dasar sampai perguruan tinggi, selanjutnya pemerintah harus bersatu dalam upaya pencegahan Narkotika di lingkungan sekitarnya. Penelitian ini bertujuan untuk menjelaskan langkah-langkah yang dilakukan oleh penegak hukum dalam penyalahgunaan narkotika, yang kedua menjelaskan prosedur pengenaan sanksi yang dilakukanoleh pengguna terhadap penyalahgunaan narkotika. Penelitian ini menggunakan metode hukum normatif. Sumber data yang digunakan adalah sumber bahan hukum sekunder yang diperoleh melalui analisis dokumen, dan analisis bahan hukum dengan menggunakan argumentasi hukum. Sumber bahan hukum dalam penelitian ini adalah bahan hukum primer dan sekunder, teknik pengumpulan bahan hukum menggunakan metode pencatatan dokumentasi dan membaca peraturan perundang-undangan yang berkaitan dengan permasalahan dan dianalisis dengan menggunakan deskriptif kualitatif. Hasil penelitian menunjukkan bahwa Langkah-langkah mencegah penyalahgunaan narkotika dapat dilakukan melalui metode promotif, preventif, represif, kuratif dan rehabilitasi, yang kedua Pengenaan sanksi pidana bagi pengguna Narkotika, dapat dikenakan sanksi pidana, yaitu dalam pasal 47, pasal 54, pasal 55, dan pasal 103 yang menyatakan pada pokoknya bahwa pecandu Narkotika dan korban penyalahgunaan narkotika dapat dikenakan rehabilitasi medis dan rehabilitasi sosial serta berkewajiban melaporkan kepada rumah sakit, pusat kesehatan masyarakat dan juga lembaga rehabilitasi medis serta rehabilitasi sosial bagi pemakainarkotika danatau orang tua atau wali bagi pemakainarkotika.
\end{abstract}

Kata Kunci: Penegakan Hukum; Narkoba; Sanksi

\begin{abstract}
Narcotics abuse has a very bad impact on the continuity of the generation of a nation. To anticipate this, it requires cooperation from all components of society, such as families, school institutions from elementary to tertiary level, then the government must unite in efforts to prevent Narcotics in the surrounding environment. This study aims to explain the steps taken by law enforcers in narcotics abuse, the second is to explain the procedures for imposing sanctions by users against narcotics abuse. This research uses normative legal methods. Sources of data used are sources of secondary legal materials obtained through document analysis, and analysis of legal materials using legal arguments. Sources of legal materials in this study are primary and secondary legal materials, legal material collection techniques use the method of recording documentation and reading laws and regulations relating to the problem and are analyzed using descriptive qualitative. The results showed that measures to prevent narcotics abuse can be carried out through promotive, preventive, repressive, curative and rehabilitation methods, secondly the imposition of criminal sanctions for narcotics users, can be subject to criminal sanctions, namely in article 47, article 54, article 55, and Article 103 which states in essence that Narcotics addicts and victims of narcotics abuse can be subject to medical rehabilitation and social rehabilitation and are obliged to report to hospitals, community health centers as well as medical rehabilitation and social rehabilitation institutions for narcotics users and / or parents or guardians for narcotics users.
\end{abstract}

Keywords: Law Enforcement; Drugs; Penalty

\section{PENDAHULUAN}

Penyalahgunaan narkotika dikalangan masyarakat bukan rahasia lagi, tersebut sekarang ini telah mencapai proporsi yang semakin meresahkan. Dalam rangka pencegahan atau pemberantasannya aparat penegak hukum telah lebih meningkatkan kegiatannya untuk terus mengadakan berbagai razia, mengingat penyebaran penyalahgunaan narkoba sudah sangat luas dan tidak pandang bulu, yang mana dalam peredarannya narkotika begitu cepat sampai di kalangan masyarakat, hal ini juga tidak menghiraukan status sosial seseorang serta calon korbannya.

Sesuai bunyi Pasal 1 Angka 1 Undang-Undang Republik Indonesia Nomor 35 Tahun 2009 tentang Narkotika menyebutkan bahwa: "Narkotika merupakan zat atau obat yang berasal dari tanaman, baik tanaman sintetis maupun tanama semisintetis, yang berakibat kepada penurunan kesadaran, hilangnya rasa, mengurangi sampai menghilangkan rasa nyeri, dan dapat menimbulkan kecanduan. Definisi narkotika mempunyai kesamaan dengan psikotropika yaitusama-sama berbentuk obat atau zat alamiah 
maupun sintesis. Perbedaan antara narkotika dan psikotropika yaitu narkotika ada yang berasal dari tanaman, sedangkan dalam pengertian psikotropika tidak disebutkan demikian.

Berdasarkan Undang-Undang RI Nomor 35 Tahun 2009 tentang Narkotika, jenis-jenis narkotika adalah Narkotika Golongan satu, yaitu narkotika yang digunakan demi kepentingan ilmu pengetahuan akan tetapi tidak digunakan dalam pengobatan/ terapi, hal ini memiliki potensi sangat besar yang dapat mengakibatkan kecanduan, seperti ganja, kokain, opium, papaversomniferum, tetrahydrocannabinol, narkotika golongan dua, yang termasuk golongan ini adalah narkotika yang digunakan dalam pengobatan sebagai pilihan terakhir dan juga digunakan dalam terapi dan atau untuk juga pengembangan ilmu pengetahuan serta memiliki potensi besar yang dapat mengakibatkan ketergantungan, seperti rasemorfan, normorfina, tilidina,petidina, morfina, narkotika golongan tiga, yang termasuk golongan ini adalahnarkotika yang digunakan dalam ilmu pengobatan dan jugauntuk terapi dan atau demi pengembangan ilmu pengetahuan serta memiliki potensi yang tidak berat yang dapat mengakibatkan ketergantungan, seperti kodeina, polkodina, etilmorfina, nikokodina, propiram (Satjipto, 2000).

Dalam Kamus Bahasa Indonesia disebutkan mengenai pengertian pengguna narkotika yaitu "Pengguna" merupakan orang yang memakai, sebagaimana diatur dalam Pasal 1 Angka 1 UndangUndang Narkotika maka dapat dikatakan bahwa pemakai narkotika merupakan orang yang menggunakan obat atau zat yang berasal dari tanaman, baik tanaman sintetis maupun tanaman semi sentetis yang dapat menurunkan dan bahkanmengalami gangguan kesadaran, menghilangkan rasa, mengurangi sampai dengan menghilangkan rasa nyeri. Pecandu Narkotika adalah orang yang menggunakan atau menyalahgunakan narkotika dan dalam keadaan ketergantungan pada narkotika, baik secara fisik maupun psikis.Penyalahguna narkotikamerupakan orang yang tidakberhak memiliki atau melawan hukum. Pecandu Narkotika secara ilmu kesehatan adalah orang sakit adiksi kronis yang bisa sembuh dan tidak mengkonsumsi narkotika lagi direhabilitasi, sedangkan secara hukum berdasarkan pasal 54 Undang-Undang No 35 Tahun 2009 tentang Narkotika, pecandu hukumnya wajib rehabilitasi. Rehabilitasi dihitung sebagai menjalani hukum (pasal 103 ayat)

Dalam ilmu kesehatan, penyalahgunaan narkotika itu dapat meracuni sistem saraf maupun daya ingat, juga dapat menurunkan kualitas berfikir yang akhirnya membahayakan berbagai organ vital si pemakai seperti halnya jantung, hati, paru-paru, ginjal, bahkan sumsum tulang, bisa terkena penyakit hepatitis, penularan HIV/AIDS dan jika sampai memakai berlebihandapat menimbulkan kematian. Penyalahgunaan narkotika juga beresiko psikososial yang mana akan mengubah tabiat seseorang menjadi pemurung, cepat marah, sering cemas, paranoid, tertekan, serta kegilaan, sikap tidak peduli lingkungan sekitar, tidak peduli dengan penampilan, melakukan tindakan kriminal, mencopet, pemalas, menjambret, dan lain-lain (FR \& Nengah, 2013).

Penegakan hukum yang dilakukan oleh aparat hukum terhadap tindakan pidana narkotika dan juga adanya putusan hakim di persidangan yang sudah memiliki kekuatan hukum tetap. Penegak hukum ini diharapkan mampu sebagai faktor penangkal terhadap merebaknya peredaran, perdagangan narkotik. Undang-undang Nomor 35 Tahun 2009 tentang Narkotika, memberikan sanksi pidana cukup berat terhadap tindakan pidana narkotika, disamping dapat dikenakan hukuman badan dapat juga dikenakan sanksi pidana denda, dalam kenyataan para pelaku tindak pidana narkotika justru semakin meningkat. Hal ini disebabkan oleh faktor penjatuhan sanksi pidana tidak memberikan dampak atau deterrent effect terhadap para pelaku tindakan pidana narkotika.

Berbagai peraturan yang telah dikeluarkan oleh pemerintah tentang narkotika dalam rangka untuk mencegah dan mengurangi tindak pidananarkotika, tetapi kejahatan mengenai tindak pidana narkotika belum dapat berantas, bahkan beberapa kasus yang telah banyak menangkap pengedar Narkotika untuk diadili serta diputus oleh Pengadilan Negeri Denpasar.

Dalam ketentuan Undang-Undang Nomor 35 Tahun 2009 tentang Narkotika, hal yang menarik adalah adanya kecenderungan untuk mengancamkan sanksi pidana secara bersamaan antara pidana penjara dan denda. Sistem seperti ini tidak dikenal dalam pengancaman pidana di KUHP, karena baik pidana penjara maupun pidana denda adalah pidana pokok.

Penelitian tentang penyalahgunaan narkotika telah banyak dilakukan sebelumnya seperti (Bunker, 2010); (Dewangga, 2014)); (Reza, 2018) membahas tentang putusan penjara karena penyalahgunaan narkoba. Permasalahan peredaran obat-obatan terlarang tersebut semakin merajalelaketikaadanya narkotika jenis baru yang beredar di Indonesia. Keberadaan obat-obatan terlarang yang semakin variatif, turut menyulitkan aparat untuk mengontrol peredarannya. Penelitian ini bertujuan untuk mengetahui 
langkah-langkah yang dilakukan oleh penegak hukum dalam penyalahgunaan narkotika, serta menjelaskan prosedur terhadap pengenaan sanksi yang dilakukan oleh pemakai terhadap penyalahgunaan narkotika.

\section{METODE PENELITIAN}

Penelitian menggunakan penelitian hukum normatif, dimana dalam penelitian hukum ini dilakukan dengan cara meneliti bahan dari buku-buku (Soekanto, 2007). Penelitian ini menggunakan pendekatan masalah perundang-undangan dan pendekatan konseptual. Pendekatan perundang-undangan yaitu mengkaji peraturan perundang-undangan yang mengatur mengenai penegakan hukum terhadap penyalahgunaan narkotika. Sedangkan pendekatan konseptual yaitu pendekatan dengan menggunakan konsep-konsep para ahli ilmu hukum yang ada hubungannya terhadap penegakan hukum terhadap penyalahgunaan narkotika. Adapun sumber data yang digunakan dalam penelitian ini diperoleh melalui studi kepustakaan (library research), yaitu: Bahan hukum primer dan Bahan hukum sekunder, bahan hukum primer yaitu terdiri dari peraturan perundang-undangan yang berkaitan dengan kesehatan dan Narkotika, sedangkan bahan hukum sekunder memberikan penjelasan mengenai hal-hal terkait dengan masalah yang diteliti, misalnya keputusan yang. Untuk mendapatkan bahan hukum dalam penelitian ini dengan menggunakan metode pencatatan dokumentasi dan membaca peraturan perundang-undangan yang berkaitan dengan permasalahan yang dibahas, disamping itu bersumber dari kepustakaan, text book, literatur/penunjang, majalah-majalah, surat kabar dan media internet sebagai penunjang bahan hukum primer (Waluyo, 1996). Setelah bahan hukum yang diperlukan terkumpul, maka akan diolah serta dianalisis dengan metode pengolahan bahan hukum kualitatif, metode pengolahan bahan hukum kualitatif dilakukan dengan memilih bahan hukum dilihat dari kualitasnya untuk menjawab permasalahan yang diajukan (Hartono, 1994).

\section{HASIL DAN PEMBAHASAN}

\section{Langkah-Langkah Penegak Hukum Dalam Mencegah Penyalahgunaan Narkotika}

Tindak pidana merupakan pengertian dasar dalam hukum pidana. Tindak pidana merupakan suatu pengertian yuridis, lainhalnya dengan istilah perbuatan jahat atau kejahatan. Tindak pidana merupakan suatu perbuatan yang memiliki unsur kesalahan sebagai perbuatan yang dilarang dan diancam dengan pidana, dalam penjatuhan pidana kepada si pelaku adalah demi terpeliharanya tertib hukum dan terjaminnya kepentingan umum (Taufik, 2013).

Pelaku tindak pidana narkotika dapat dikenakan sanksi sesuai dengan Undang-Undang Republik Indonesia Nomor 35 Tahun 2009 tentang Narkotika, hal ini dapat diklasifikasikan sebagai berikut :

a) Pengguna akan dimasukkan dalam ketentuan pidana sesuai bunyi Pasal 116 Undang-Undang Republik Indonesia Nomor 35 Tahun 2009 tentang Narkotika, yang diancam hukuman minimal 5 (lima) tahun dan paling lama 15 (lima belas) tahun penjara.

b) Sebagai pengedarakan dimasukkan dalam ketentuan pidana sesuai bunyiPasal 81 dan Pasal 82 Undang-Undang Republik Indonesia Nomor 35 Tahun 2009 tentang Narkotika, yang diancam hukuman paling lama 15 (lima belas) tahun penjara plus denda.

c) Sebagai pembuat (produsen) akan dimasukkan dalam ketentuan pidana berdasarkan Pasal 113 Undang-Undang Republik Indonesia Nomor 35 Tahun 2009, yang diancam hukuman paling lama 15 (lima belas) tahun penjara/ seumur hidup/ bahkan hukuman mati plus denda.

Berdasarkan amanat Undang-Undang No 35 Tahun 2009 tentang Narkotika, dari hasil pengamatan dan penelitian, terdapat beberapa langkah upaya pencegahan dan penanggulangan Narkotikayang harus dilakukan seluruh lapisan masyarakat, sebagai berikut:

1) Metode promotif disebut juga program pre-emtif dan program pembinaan. Program ini diberikan kepada lapisan masyarakat yang belum mengenal danmemakai Narkotika. Program ini yang paling tepat diterapkan di lembaga-lembaga kemasyarakatan yang difasilitasi dan diawasi oleh pemerintah.

2) Preventif (pencegahan), merupakan program untuk membentuk masyarakat yang mempunyai ketahanan, kekebalan dan komitmen anti terhadap Narkotika). Pencegahan adalah lebih baik daripada mengobati dan pemberantasan. 
3) Represif (penindakan) merupakan programuntuk menindak dan memberantas penyalahgunaan Narkotika melalui jalur hukum yang dilakukan oleh aparat keamanan maupun penegak hukum serta dibantu oleh masyarakat.

4) Kuratif (pengobatan) merupakan program penyembuhan para korban baik secara medis maupun non medis yang bertujuan untuk memulihkan dan menagangi para korban narkotika. Di Indonesia sudah banyak didirikan tempat-tempat penyembuhan dan rehabilitas atau pecandu Narkotika.

5) Rehabilitatif (rehabilitasi) merupakan programyang dilakukan di saat pengobatan selesai dan para korban tidak kambuh kembali "ketagihan" Narkotika. Rehabiltasi berusaha untuk menyantuni dan memperlakukan secara wajar para korban narkotika agar dapat kembali kemasyarakat dalam upaya sehat jasmani dan rohani.

\section{Pengenaan Sanksi Pidana Terhadap Pengguna Penyalahgunaan Narkotika}

Narkotika dapat menyebabkan efek dan dampak sangat buruk bagi kesehatan mental dan fisik. Meskipun demikian terkadang jenis obat masih dipakai dalam dunia kedokteran, namun hanya diberikan bagi pasien-pasien tertentu, bukan untuk dikonsumsi secara umum dan bebas oleh masyarakat. Oleh karena itu obat dan Narkotika yang disalah gunakan dapat menimbulkan berbagai akibat yang beraneka ragam, seperti: gangguan pada kulit dan organ-organ tubuh, hilangnya suasana nyaman dan tenteram dalam keluarga; mengganggu suasana belajar mengajar bagi pelajar atau mahasiswa sehingga prestasi belajar turun drastis, hilangnya kepercayaan diri, gangguan mental, mafia dan tidak pernah beribadah.

Penerapan sanksi hukum berupa rehabilitasi bagi pecandu dan pemakai sebagai pelaku penyalahgunaan narkotika tentunya akan mengurangi kelebihan kapasitas lembaga pemasyarakatan. Kelebihan kapasitas hunian ini menimbulkan permasalahan antara lain gangguan kesehatan mental, penyimpang perilaku seksual, penularan penyakit, penularan kejahatan dan terjadinya tindak kekerasan, timbulnya lingkungan yang kumuh serta rendahnya kualitas pelayanan kepada narapidana. Di samping itu, dapat mengurangi peredaran gelap Narkotika itu sendiri, karena putusnya mata rantai peredarannya. Terdakwa diperiksa dan diadili dipengadilan bertujuan untuk membuktikan apakah perbuatan atau tindak pidana yang dilakukan dapat dipertanggungjawabkan dan apa sanksi pidana yang tepat kepada orang yang melakukan tindak pidana tersebut (Achmad, 2014).

\section{SIMPULAN DAN SARAN}

\section{Simpulan}

Berdasarkan hasil analisis data, dapat disimpulkan bahwa langkah-langkah yang dilakukan oleh penegak hukum dalam upaya pencegahan tindak pidananarkotika yang dapat merusak generasi penerus bangsa dan negara, dan juga merugikan diri sendiri, teman, keluarga, serta lingkungan masyarakat tanpa mengenal strata ekonomi seseorang. Langkah itu dapat dilakukan dengan melalui beberapa lingkup yaitu, kampusmaupun sekolah, masyarakat, tempat kerja, keluarga, pemerintah, dan profesi. Untuk mencegah penyalahgunaan narkotika dapat dilakukan, diantaranya: Metode Promotif, Metode Preventif, Metode Represif, Metode Kuratif dan Rehabilitasi, yang kedua Pengenaan sanksi pidana bagi pengguna Narkotika diatur dalam pasal 47, pasal 54, pasal 55, dan pasal 103 yang menyatakan pada pokoknya bahwa pecandu Narkotika dan korban penyalahgunaan narkotika dapat dikenakan rehabilitasi medis dan rehabilitasi sosial serta berkewajiban melaporkan kepada rumah sakit, pusat kesehatan masyarakat dan juga lembaga rehabilitasi medis serta rehabilitasi sosial bagi pemakainarkotika danatau orang tua atau wali bagi pemakainarkotika.

\section{Saran}

Ada beberapa yang disarankan penelitia adalah Untuk mencegah dan memberantas penyalahgunaan narkotika langkah-langkah penegak hukum diharapkan kepada pemerintah agar tidak terus menerus terjadi penyalahgunaan Narkotika dilingkungan masyarakat terutama dilingkungan generasi muda maka perlu adanya sosialisasi dan penyuluhan terhadap dampak penyalah gunaan Narkotika. Selanjutnya diharapkan pemerintah selaku pengambil kebijakan dapat merumuskan perundangundangan dan peraturan-peraturan yang lebih ketat dalam pengawasan dan produksi Narkotika di Indonesia. Maka, dari peraturan-peraturan itulah masyarakat di Indonesia dapat terjaga dari ancamanancaman Narkotika yang beredar di lingkungan masyarakat. 


\section{DAFTAR PUSTAKA}

Bunker, R. J. (2010). Strategic Threat: Narcos and Narcotics Over view.

Dewangga, W. J. (2014). Penegakan Hukum Tindak Pidana Penyalahgunaan Narkotika dengan Pelaku Anggota Kepolisian (studi Kasus di Wilayah hukum boyolali). Urisprudence, 4(2).

FR, J. L., \& Nengah, S. W. (2013). Narkoba, Psikotropika dan Gangguan Jiwa Tinjauan Kesehatan dan Hukum. Nuha Medika.

Hartono. (1994). Penelitian Hukum di Indonesia pada Akhir Abad 20. Alumni.

Reza, F. (2018). Verdict Prison For Drug Abuse. 1(2).

Satjipto, R. (2000). Ilmu Hukum. Citra Aditya Bakti.

Soekanto, S. (2007). Faktor-Faktor yang Mempengaruhi Penegakan Hukum. PT Raja Grafindo Persada.

Taufik, M. (2013). Hukum Perlindungan Anak dan Penghapusan Kekerasan. Rineka Cipta.

Waluyo, B. (1996). Penelitian Hukum Praktek. Sinar Grafika. 